\title{
Good Practices and Sustainable Tourism of Marginal Mountain Areas. The Case of Wine Cannonau in Mamoiada, Sardinia - Italy
}

\author{
Donatella CARBONIa, Giampietro MAZZA' , Marius ANDRA ${ }^{b}$, Andreea ANDRA-TOPÂRCEANUc1 \\ aUniversity of Sassary, Departament of Humanities and Social Sciences, Via Roma, 151, Sassari, Italy \\ bValahia University, Faculty of Geography, Doctoral School of Economic Sciences, Av. Lt. Stancu I., 35, \\ Târgoviste, Romania \\ cUniversity of Bucharest, Faculty of Geography, Av. N. Bălcescu, 1, Bucharest, Romania
}

\begin{abstract}
Mountain regions have been modified by human activity for centuries, which lead to more or less of significant changes in their ecosystems and consequently in landscapes. Some of these changes have been generated by traditional farming practices, such as the viticulture, giving distinctive shapes and identities of the space. Even if in many areas, the farming traditions have been abandoned as the consequences of technological progress applied in agriculture, Sardinia is a good example of vineyards cultural heritage preservation. Thus, linking this cultural heritage to the wine tourism, and promoting good practices at local initiatives, Sardinia limited the depopulation of the mountain areas. A very successful example of the increasing of positive tourism impact on territory planning, over the past few years, is the municipality of Mamoiada, in central Sardinia. The paper highlights the role of the using of environmental, cultural and identity tourist resources of Sardinian territory as far as they are part of good practices and furthermore, they could be the basis of sustainable development strategy. Moreover, the aim of our work is to investigate how the cultural, identity, landscape and socio-economic impact on the wine sector plays an important role for the rural community of Mamoiada.
\end{abstract}

Keywords: good practices, Mamoiada-Sardinia, viticulture, marginal mountain area, Cannonau wine, sustainability

\section{Basic Issues Related to Disadvantaged Mountain Areas}

In the third millennium, which is defined by sustainable development paradigm, researchers and planners have to investigate, analyse and assess the role, especially in the fragile environments, of the local populations, to provide solutions through changes and planning, keeping an equilibrium between human needs and long terms preservation targets. In this regard, the analysis of the fragile and marginal areas, where the anthropic pressure is lower, as mountain regions are, should focussed on the human-environment interactions, the availability of natural resources, the efficiency of economy, and the social welfare (Ciaschi, 2014; Cunha, 2003).

An applicative study of a given territory as a fragile environment has to investigate, analyse and assess the role of the local populations that has defined it, and its changing and planning in accordance with their needs and finally it could provide solutions for sustainable development. In fact, the analysis of fragile and marginal areas where the anthropic pressure is weaker, such as mountain regions, should concentrate on the human actions and its relations with environment, both with regard to the availability of natural resources and with the efficiency of economic and social factors (Ciaschi, 2014; Cunha, 2003).

\footnotetext{
${ }^{1}$ Corresponding author: Andreea ANDRA-TOPÂRCEANU; E-mail: andreea.andra@geo.unibuc.ro, Received: November; Revised: November; Published: December
} 
For Ciaschi (2014), every mountain area is an environment with strong territorial identity having its own cultural and social features, which could be the starting point for the development of territories specialized in certain sectors: agriculture and related activities, natural, cultural and tourism resources. The increase of human impact on the mountain areas has influenced the trends of polarization between marginalization and modernization especially in agriculture and the result was a very segmented landscape; if on the one hand it has favoured the recognition and the limits, on the other it has intensified the abandonment of the territory. Over time, efforts have been made up to promote development policies in mountain areas, both at community level with cohesion policies and at local level with actions aimed at counteracting de-territorializing dynamics and improving the well-being of local communities (Price et al., 2019). Thus, it is important (to) encouraging the development of a high quality local production, often linked to agri-food and agricultural production (Bentivoglio et al., 2021), through sustainable farming systems, even if they are smaller in size and production (yield) than the rest of farming from lowlands (lower than $40 \%$ of national average productivity) (Euromontana, 2021; Bratoveanu et al., 2021).

One of the most important tools, which is spread and increasingly strength in mountain areas and which contributes not only to limiting depopulation but also to strengthening the socioeconomic structure of the territory and contributing to its development, is certainly tourism. It seems necessary to point out that tourism has sometimes "impoverished" tourist destinations, depriving them of their resources. For this reason, tourism sustainability of mountain areas (Bošković et al., 2020; Milićević et al., 2021) requires an integrated territorial planning, where its inhabitants assume efforts through their practices of economic development of the community, and this specific process takes on substantial importance as it allows the differentiation of the local economy (Khartishvili et al., 2020).

Cultural tourism is certainly compatible with local socio-economic activities, especially in mountain and rural areas; it integrates with the primary sector and reinforces it by encouraging initiatives to develop the territory in a systemic perspective (Št'astná et al., 2020).

The research hypothesis from which our approach started was determined by the relationship between boosting the tourism phenomenon in abandoned territories leading to repopulating by increasing the youth specialists' interest, which in turn would improve the development of tourism and territorial development.

The main objectives of the paper were to highlight and demonstrate that traditional economic activities abandoned or not, remain resource-efficient for the socio-economic development of rural territories when their tourism function is activated. Moreover, the tourist function of those tangible and intangible resources with roots in historical, social and economic heritage needs calibration in line with the requirements of the current tourism phenomenon.

\section{Methodology}

The intrinsic knowledge of the qualitative and quantitative characteristics of those tourism resources and products is important. From a methodological point of view, in order to understand how the mountain area of Mamoiada has an increasing role in wine tourism of the region, we accessed the bibliographic and demographic statistics in order to perform qualitative and quantitative analysis. Previous studies and data base analysis (ISTAT, 2020; 2021; Consorte et al., 2021) reveal the origin and the peculiar features of touristic resources.

The exploratory surveys were applied through the field methods of the interviews aimed at collecting data regarding the growth of the harnessing tourism resources and products. The 
interviews were applied on entrepreneurs and employees of museum institutions. The survey, aimed to all stakeholders in order to determine the current and future policies of this peculiar Sardinian area, has served the authors to find out territorial identities and to lay the foundations for a wider work, which is still being worked on and which intends to propose alternative systemic local development strategies. Over 200 wineries, museum, artisan wine-makers, restaurants, hotels and tourists, were considered subjects of our surveys on the spot to better perceive the growing importance that is gradually take by the wine production for the investigated territory.

In order to reach the main objective, data collected from surveys and field work, observation and inventory mapping, are drawn from very comprehensive perspective, historical, geographical, socio-economic, regarding the distribution of winegrowing areas and their characteristics, using ArcGis 10.3.1.

Historical analysis were performed on demographic and data extended from the 17th century until nowadays especially of tourist flows data over the last two decades (ISTAT, 2021) and historical photos in order to demonstrate the features of very recent and complex relations between demographic and tourism phenomena.

\section{Geographical settings of case study}

Geographical characteristics of Sardinia have always been favourable to viticulture and being linked with a given historical background, they had created the identity of Sardinian vineyard landscapes, which became nowadays cultural and tourism resources. Topography, through its configuration, roughness and surface aspect, simultaneously at the same time it can be favourable to traditional agriculture and tourism through its functional and aesthetic values or can be disadvantageous for accessibility, modern agriculture and population. Even if it does not reach significant altitudes, the peculiarity of the Sardinian Mountain is emphasized mainly by the characteristics of the reliefs in relation to the long geological history, the paleogeographic events and the lithological types, which have determined its isolation, the landscape and the environment.

Sardinia is mostly a hilly and mountain region, where more than $75 \%$ of the surface has elevation exceeding $300 \mathrm{~m}$ up to $1800 \mathrm{~m}$ (m.s.l) and has an asymmetric spatial distribution of geomorphologic units (Figure 1).

The municipality of Mamoiada is the case study, is shaped such as an amphitheatre from 300 to $800 \mathrm{~m}$ elevation, having average elevation of $644 \mathrm{~m}$, with gentle slopes $\left(0^{\circ}-20^{\circ}\right)$, where Cambisols are covered by pastures maquis and garigue, grass-agricultural developed under a temperate, semicontinental attenuated and semi-humid climate (Table1).

Table.1 Summary of climate data

\begin{tabular}{lllll}
\hline & $\begin{array}{l}\text { difference in } \\
\text { elevation }\end{array}$ & $\mathrm{T}\left({ }^{\circ} \mathrm{C}\right)$ & $\begin{array}{l}\text { Pp } \\
(\mathrm{mm} / \mathrm{an})\end{array}$ & Subtype \\
\hline Sardinia & $1834 \mathrm{~m}$ & $11-17$ & $450-1110$ & $\begin{array}{l}\text { Euoceanico accentuato } \\
\text { Euoceanic attenuated } \\
\text { Temperate-oceanic attenuated }\end{array}$ \\
& & & & $\begin{array}{l}\text { Semicontinental attenuated } \\
\text { Mamoiada }\end{array}$ \\
& $390-1050 \mathrm{~m}$ & $8.2-18.8$ & $530-600$ & $\begin{array}{l}\text { Euoceanic attenuated, } \\
\text { Temperate, semicontintental } \\
\text { attenuated, semi-humid }\end{array}$ \\
\hline
\end{tabular}

Sources: Climate-Data, 2021; Weather Atlas, 2021. 
In Sardinia inlands the high hills and mountains are mostly shaped through gentle slopes and they are forested. Sardinia has a divergent and high density drainage network and its river systems are characterized by hydrological risk processes because of the climatic influences.

The Mediterranean-type climates are characterized by high radiation values, high sunlight exposure, rainfall and air humidity variations (Table 1.) which imply seasonal soil moisture variations, and all these may increase the quality of winemaking products.

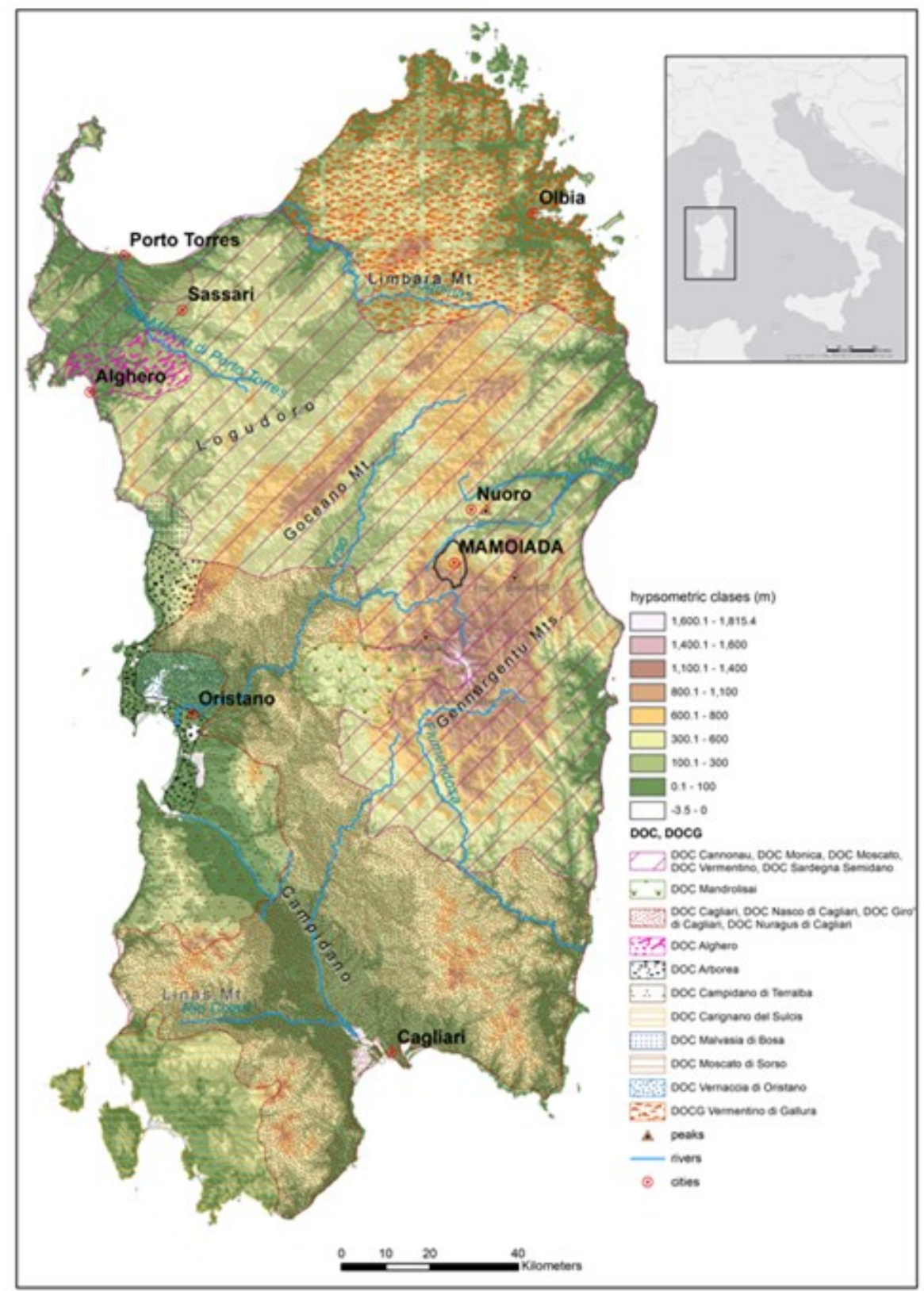

Figure 1. Elevation affects the geographical distribution and typologies of DOC wine-growing areas. Map shows the predominance of Cannonau, Monica and Moscato vineyards in the highlands of Sardinia. Processed by authors using data Sentinel, Laore ARSA and Federdoc data source.

The pluvial variations are over the year and according to the difference in elevation. Thus, over $75 \%$ of rainfalls are recorded from October until March and fewer precipitations in the other 
seasons. Furthermore, the difference in elevation of mountain regions (Table 1) generate an increase of annual average rainfall by $90 \mathrm{~mm}$ every 100 meters (Bacchetta et al., 2009).

Hypsometric ranges were made through a descriptive interpolation between the geographical distribution of landscape elevations, variety of rocks, climate impact on grapevine productivity, spatial distribution of soils such as Cambisols, Leptosols and vineyards typologies (Figure 1). There are many large areas favourable for viticulture as a consequence of multiple combination of these terroir factors. The geographical distribution of DOC Cannonau and other Monica and Moscato vineyards are commonly distributed on the magmatic and metamorphic highlands of Sardinia, which gives the grapes vine special characteristics.

Furthermore the Autonomous Region of Sardinia, which Mori (1975) defined as "the most original region of Italy that is the one that is most detached from its medium characters" is characterized by its territorial isolation and its low population density (Minnei, 2018), with rates ranging from 100 inhabitants $/ \mathrm{km}^{2}$ in urban areas, to 70 inhabitants $/ \mathrm{km}^{2}$ in the lowlands and 40 inhabitants $/ \mathrm{km}^{2}$ in mountain areas, with an average of 66 inhabitants $/ \mathrm{km}^{2}$ and a population of $1,598,225$ people (ISTAT data, 2021), distributed over a territory corresponding to $24,100 \mathrm{~km}^{2}$. Even if more than $80 \%$ of the regional territory is characterized by being hilly and mountainous (according to the data provided by the ISTAT classification for mountain municipalities), with about $18 \%$ of the flat territory on which urban areas are extended, the regional demographic distribution is somewhat heterogeneous. Despite the island's large territorial extent, the population is rather fragmented and centralized in urban areas from lowlands.

Urbanization is quite polycentric, polarized in medium-sized cities that act as an attraction pole, around which there are fewer urban agglomerations and rural spaces. The inners areas of Sardinia manifest multiple forms of isolation, with socio-economic inequalities, sometimes connected by the geomorphological conformation of the territories.

The analysis of the territorial planning underlines that only a little more than $1 \%$ of the provincial area of Nuoro is urban, with the exception of a small plain area near Ottana, mainly hilly and mountainous. Thus, the environment is rough, with uneven surfaces which are less accessible also because of the less efficient infrastructure, leading to regional isolation (Mazza et al., 2018) and depopulation in the inner areas of the province of Nuoro. The municipality of Mamoiada, which was chosen as a case study for this paper, is located in central Sardinia, within the Province of Nuoro, which covers an area of 5,637.96 km, on which, as of January 1, 2021, a population of 202,951 inhabitants resides out of a total of 74 municipalities and a relative population density of 36 inhabitants/km (ISTAT data), demonstrating strong demographic criticalities.

The relative density of residents recorded in Mamoiada highlights critically demographic values (ISTAT, 2021, January $1^{\text {st }}$ ). The population of 2,432 inhabitants is distributed over a limited area of $48.43 \mathrm{~km}^{2}$ and a population density of just over 50 inhabitants $/ \mathrm{km}^{2}$ (Table 2).

Within the aforementioned province, the mountainous and high hilly territory imply sufficient water reserves for municipality of Mamoiada, which has favoured the settlements, being populated since Neolithic. Also, the archaeological traces have demonstrated that this environment is representing an important resource for the territory by its distinguished natural characteristics.

Today the human impacts show the common patterns of the highlands, inlands and rural areas, however with less evident influences on natural environment, compared to other urban areas, belonging of Nuoro Province. 
These areas are characterized by insufficient tourism services that leads to less accessibility and discontinuity of them (Dematteis, 2013). Their historical identity values, natural and cultural landscape and local resources, could facilitate the development of endogenous processes, increasing its own centrality (Carbone and Ciaschi, 2014).

The local community, with its own combination of traditions and knowledge handed down over time, reveals the features of an intense link with the territory, contributing to nourish the widespread spirit of identity. To the sense of belonging does not correspond, sometimes, a proportionate ability to know how to value the local environment (Dematteis and Governa, 2005) that, substantially, may not fully express its potential.

In the case of Mamoiada, in last years, private and local initiatives have encouraged endogenous development strategies, integrating the same local needs in line with the principles of sustainability.

This is why the Mamoiada case was chosen from among the most disadvantaged areas in terms of accessibility and depopulation, in order to demonstrate that the implementation of good practices can continue with the development of integrated strategies for the recovery and development of these areas.

\section{Results}

The demographic dynamics of Mamoiada (Figure 2) is similar to other small municipalities of the inner and mountain areas of Sardinia. Historically, it has been faced with major difficulties in converting from traditional rural society to a new model which is often difficult to identify but which is taking on a well-defined and precise pattern of Mamoiada.

The resident population, which at the first available census (Table 2), that of 1688, was equal to 751 inhabitants, had risen to 1,456 inhabitants in 1781 and to 2,060 in 1881, revealing a tendency to the demographic increase that lasted until the second post-war period, reaching a maximum of 3,233 inhabitants in 1961 (ISTAT data).

Table.2. Population of Mamoiada

\begin{tabular}{|l|l|l|l|l|l|l|l|l|l|l|l|l|l|l|l|}
\hline Year & 1688 & 1781 & 1861 & 1901 & 1911 & 1921 & 1931 & 1951 & 1961 & 1971 & 1981 & 1991 & 2001 & 2011 & 2021 \\
\hline Residents & 751 & 1456 & 1927 & 2332 & 2632 & 2549 & 2724 & 3098 & 3233 & 2795 & 2713 & 2633 & 2580 & 2559 & 2432 \\
\hline
\end{tabular}

Sources: (ISTAT, 2021).

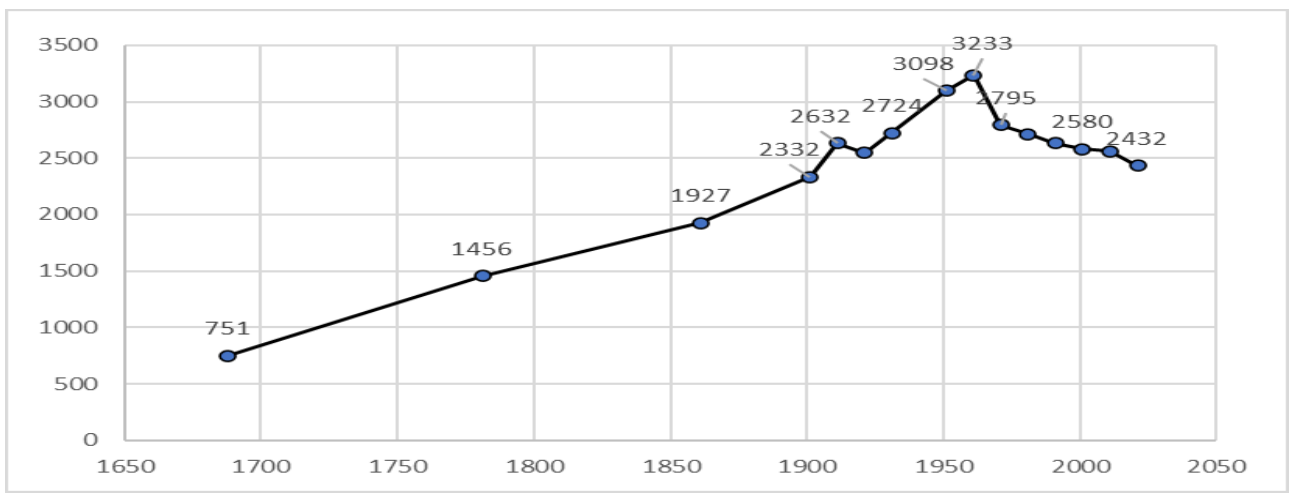

Figure 2. Demographic evolution of Mamoiada. Source data: ISTAT.

This period of growth was followed by a sharp demographic decline between the sixties and the seventies, driven mainly by the emigration phenomenon. This phase of migration was strictly 
linked to the rural context and the pastoral world, emphasize important social and cultural effects caused by widespread migration of shepherds from the inlands to other areas (Gentileschi, 1995).

This migration process has had a decisive impact on the economic and demographic systems, causing not only high percentage of population abandonment, from the inner Sardinia Island but, even the companies were exposed to this aggressive kind of "migration", relocating their economic activity.

The dynamic of this migratory phenomenon and the abandonment of the origin lands may be define as a new territory with a new destination and functions, if the deculturizing and deterritorializing processes are certainly configured (Deleuze and Guattari, 1975; Haesbaert, 2010; 2013). These territorial and demographical imbalances had affected the local socio-economic structure of inlands settlements and have exposed the mountain areas to a territorial marginalization, by throwing their own local and ancient development model into crisis. Subsequently, between the eighties and the 2000s, a slight stabilization of demographic trends of Mamoiada, was recorded due to economic development of nearby Nuoro provincial capital (only $17 \mathrm{~km}$ distance), allowing commuting on short intervals of time.

In recent years, the resident population has a slight demographic concentration, but less visible than neighbouring municipalities, being increasingly affected by evident demographic declines, with a sharp decrease in the birth rate and a substantial increase in the old age index. In the specific case of Mamoiada, in 2020, the old age rate is $159 \%$, expressing a ratio of over 65 years and young people under 14 years of 1.59 to 1, with 159 elderly every 100 young people, however, lower than the national average, which is $179 \%$. Despite the demographic decline of Mamoiada, still doesn't assume strikingly sharp difference, but the curve tends to flatten.

Brandis, in 1979, highlighted how «the geographical characteristics of the Sardinian territory are highly favourable for the livestock sector, which in the agricultural sector has the highest income component» (Brandis, 1979: 11). This aspect is certainly higher in the inner areas of the island than in the coastlands, being well visible in Mamoiada. It is basically a community that, from an economic and social point of view, has often found itself in a state of balance between agriculture and livestock-raising (Casalis, 1856; Corsale and Iorio, 2009); besides these, the contributions of viticulture and craftsmanship of wood, with the realization of the precious masks of the Mamuthones, has been detached.

This socio-economic structure has allowed Mamoiada, such as the other inlands and rural areas of Sardinia, to preserve its cultural elements and extremely valuable identities (Le Lannou, 1941), and these ones are still identities and symbols of the Mamoiada community.

Currently, the local economy and society of Mamoiada are strongly influenced by the wine sector, through the increasing production and spatial extension. Thus, the cultural landscape is reshaped by the wine-growing which becomes an attractiveness pole for tourists, entrepreneurs and new inhabitants. The agro-cultural landscape, especially wine-growing one is, therefore, a tourist resource favourable to territorial planning and economic development, as recognised by the European Landscape Convention of 2000 and strongly aligned with the new European model of rural development (Sotte, 2010) based on the integration and sustainability principles. According to the European Landscape Convention, Florence, October 20 ${ }^{\text {th }}, 2000$, "noting that the landscape fulfils important functions of general interest in cultural, ecological, environmental and social terms, constitutes a favourable resource for economic activity, and that, if properly safeguarded, managed and planned, can contribute to job creation". 


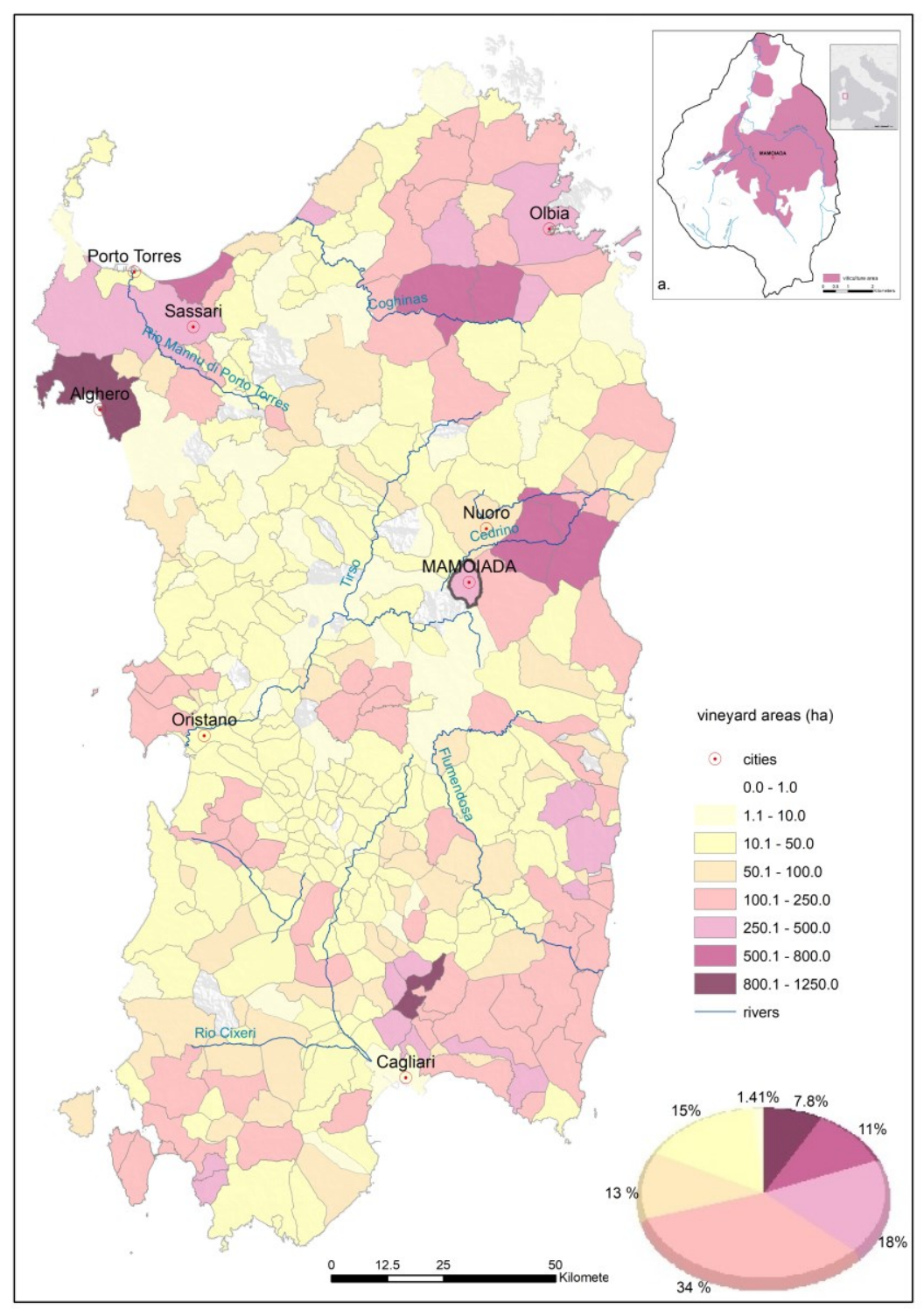

Figure 3. Distribution of wine-growing areas related with settlements; a) wine-growing area of Mamoiada Municipality. Sources: ISTAT, 2021.

Sustainability strictly concerns the agro-cultural landscape in its value to be passed on to future generations, revitalizing the role of agriculture, moreover traditional one in conservation, management and care of the territory planning.

Involving of local communities consist in the ability to satisfy individual and social well-being, benefiting the quality of life of the population and intervening in the definition of the identity of places, which "they are a product of social actions and the way in which the same people give themselves a representation" (Jess and Massey, 2001).

\section{Discussions}

A significant identity, cultural, social and economic value is certainly played by wine production, which in Sardinia has historically local communities involved.

In Sa Osa (Cabras), near Oristano, were found the first traces of the presence of wine in Sardinia, with the discovery of about 15 thousand seeds of vine dating back to the Nuragic period 
(cca. 20th century BC), deposited in some wells dug into the rock and datable between middle and late bronze period. These represent the oldest grape variety in the western Mediterranean and provide "new and fundamental information on wine-making in the Nuragic age" (Bartoloni, 2012).

In addition, protohistoric evidence on the presence of grape seeds is found at the Nuraghe Duos Nuraghes in Borore, and the Nuraghe Bau Nuraxi in Triei, emphasizing the knowledge acquired by the island population (Zucca, 2009). As for the winemaking process, the first evidence dates back to the $9^{\text {th }}$ century $\mathrm{BC}$, with the discovery of the "oldest winemaking laboratory in Sardinia, from which comes a press for marc" near Cagliari, in the countryside of Monastir (Carboni and Ginesu, 2007).

As noted by Carboni and Ginesu (2007), a fundamental role for the spread of viticulture in Sardinia is due to the Spanish and Aragonese domination, which introduced on the island many vines, including Cannonau. However, the transition from marginal agriculture to be one of the main sectors of the Sardinian economy can be dated between 1870 and 1880, spreading on a large scale and reaching also the inland and mountain areas of Sardinia. Also, in Mamoiada the wine production has a secular tradition, synthesizes the local culture, identity and history of the community and their economy.

The Laore Report of 2020 on the wine supply chain of Sardinia shows the role played by this economic sector. In this community analysed there are almost 300 hectares of vineyards (Laore, 2020 ) and approximately $98 \%$ of that are the cultivated surface with Cannonau wine grapes, so it is clear that the viticulture has great importance in Mamoiada (Figure 1, 3).

In recent years the youth are returning in Mamoiada drawn to the increasing development of the wine economy and consequently the number of employees in this sector is growing. Currently in Mamoiada there are 31 companies that bottle local wines, with a total of 400,000 bottles a year. That means and synthesize not only the long wine tradition but the strong will, for the community, to enhance the values of the territory contributing to local development and, thus indirectly, combating the phenomenon of depopulation.

\subsection{New land uses and new forms of sustainable tourism in Mamoiada}

Recently, local communities and territorial actors are carrying out development initiatives based on endogenous resources, territorial identities and local culture. An essential element is certainly the ability to partnership, implying members of the community, involving stakeholders for more territories, in order to create a given cohesion that generates economic stability. In mountain areas, the enhancement of the territory and its products (Bratoveanu et al., 2021) becomes a tool not only for development but also to mitigate depopulation.

In the case of Mamoiada, the territorial, cultural, economic and identity role played by wine is obvious through relaunching of the local economy and by creating self-awareness. The creation of two cultural associations, which are the bearers of socio-economic and territorial interest, linked to the wine sector, only reinforces this aspect.

For the local community, the recognition of quality of wine and the exports generates an intense tourist phenomenon recording a constant increase in the demand for wine tourism and visits of the cellar. Another important strategic element, moreover, and resource for the territory, is certainly the landscape, both natural and cultural, in which the presence of vineyards predominates. The landscape represents the whole of the natural and anthropic elements of a given area, which give it a tourist value by its aesthetic, cultural, identity and symbolic 
components reflects efficient tourist resources. These are peculiar landscapes, both for the environmental aspects and for the result of the anthropic action. These landscapes also play an important role in the development of sustainable forms of tourism, which is essential for local development.

The final product, the bottle of wine, therefore becomes much more than a mere product; it encloses the historical and cultural identity of people. Also related to the primary production sector, specifically the agricultural and pastoral sector, are other valuable products of food and wine chain endogenous, such as bread Carasau and Pecorino cheese (especially Fiore Sardo DOP and Pecorino Sardo DOP) whose systemic value is a key factor in local development.

The masks of the Mamuthones and Issohadores are undoubtedly an important distinctive element, as well as a resource, which underlines the close link between the community and the territory. It is certainly the most famous masks in Sardinia, which represent two figures, both generally masculine, complementary and indivisible.

As Corsale noted "the intangible heritage of Mamoiada, in particular the ancient tradition of the winter and carnival masks of the Mamuthones and Issohadores, makes the local context unique and recognizable in the ethnographic landscape and regional, national and international tourism" (Corsale, 2013). This highlights the identity role played by masks, understood as intangible heritage in which not only the local community is identified, but through which Mamoiada is recognizable, both at regional and international level. The emphasis of the masks finds expression through the job carried out from some local territorial actors, in connection with Museum of the Mediterranean Masks (Figure 4), that "stands out both for its special thematic and for its international scope and not only local", aiming to enhance the traditional masks presented in the Mediterranean and the Balkans (Corsale and Iorio, 2008).

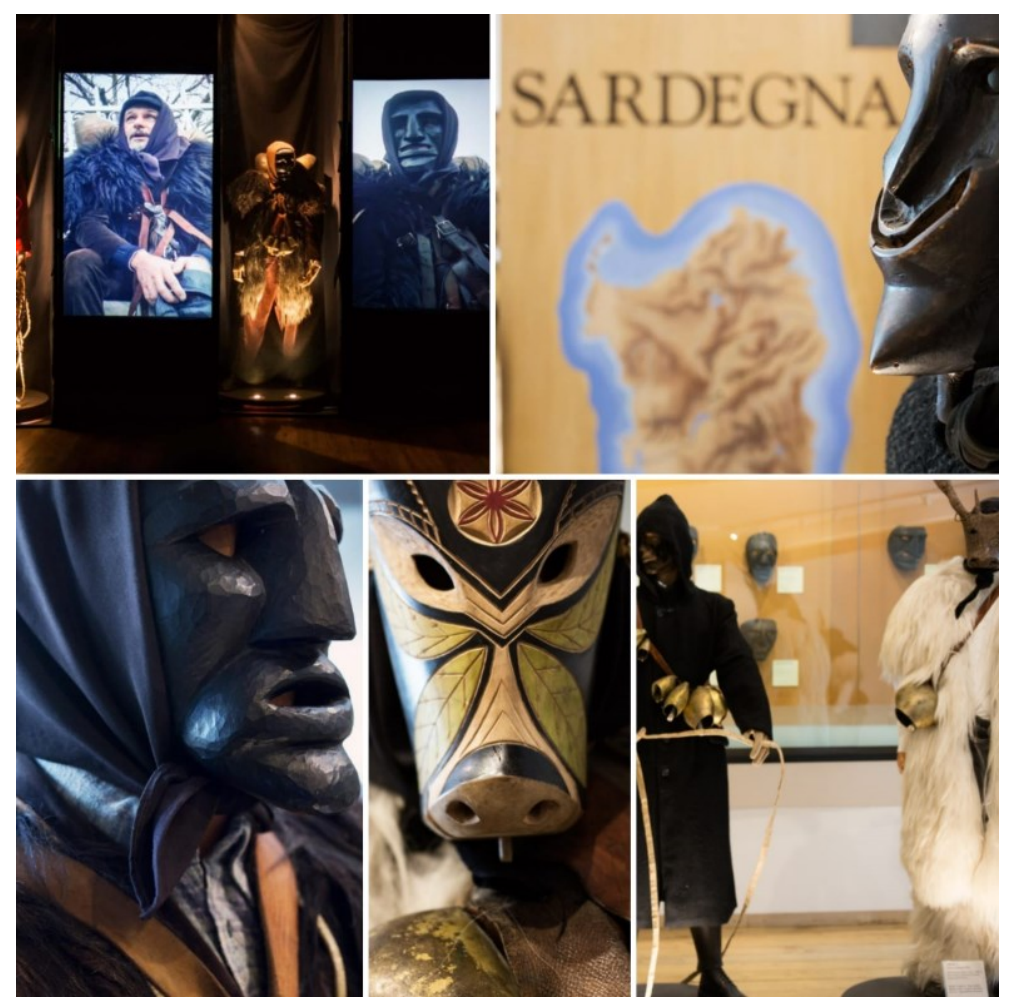

Figure 4. Museum of the Mediterranean Masks. Source: by Maurizio Olla, Museo delle Maschere Mediterranee. 
The Museum consists of three halls, a multi-vision one and an exhibition one, in which you can observe the masks of the carnival of historical region of Barbagia, and also those of other European areas, such as the Alps, Croatia, Greece, Slovenia and Spain.

One of the initiatives promoted by the Museum is the creation of cultural, food and wine itineraries that expand the tourist offer of the area, involving local artisan shops and wine producers. At different scales, the Museum provides the implementation of the touristic offers integrating the museums and other cultural structures from neighbouring municipalities of Nuoro, such as Orgosolo and its murals.

Interesting archaeological documentation from the territory of Mamoiada, which demonstrate the anthropic presence on site in prehistoric times, have great importance, defining the landscape, environmental and cultural. In this sense it is well noticed, from the historical-cultural and tourist point of view, the presence of numerous Nuraghi, Domus de Janas and Menhir, one of which, called Pedra longa was described by La Marmora in his Atlas, 1830. Cultural heritage is also the Stele of Boeli, commonly known Sa Pedra Pintà (Figure 5), decorated at the front by several concentric circles intersected by a straight engraving that decorate the slab. Its size is $2,67 \times 2,10 \times 0.57$ meters and represents an extremely important tourist attraction.

It can be said that the municipality of Mamoiada fits into a much wider dynamic cultural context, involving neighbouring municipalities and if properly put in place, can be an indispensable tool to carry out effective and efficient local development strategies.

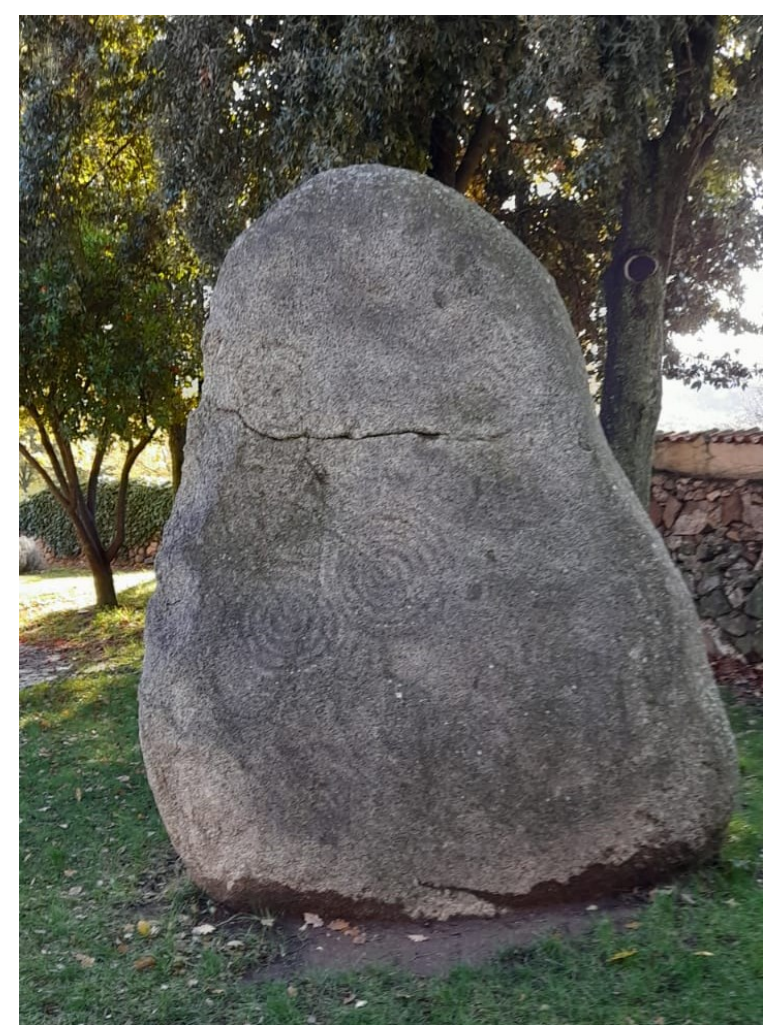

Figure 5. Sa Pedra Pintà, Mamoiada. Source: The authors' archive.

\section{Conclusions}

In rural areas, the development of sustainable tourism can certainly encourage the creation of multiple benefits, both for the territories and for the communities involved. Encouraging the 
economic development should limit the depopulation. In the case of wine tourism, it is important to emphasize the overcoming of the issues linked to the seasonality of the tourism phenomenon, knowing that it could be developed throughout the year. Exploiting the entire wine-making processes that follow one another, ranging from the harvest to the wine tasting in the cellar, should be included in tourism activities, too. The work has demonstrated the dominant role played by wine for the development of Mamoiada, and how this acts in a broader perspective, not only defining the local cultural landscape, but, in the continuous evolution of the territory development.

A tool tourism development is still partially unexpressed but present on the area is certainly that of the Cannonau wine trail. The Wine trails, in Italy, were formally born in 1999 (Law 268, 1999) with the aim of connecting in a systemic perspective the different territorial actors and create routes to promote the development of wine tourism. Along the wine trails the historical, cultural and natural resources are linked with tourist organizations of the territories, in which there is a significant wine production (Manola, 2020). The Region of Sardinia, since 2009, recognizes seven Wine Trails, including the Wine Trail DOC Cannonau that cross through Mamoiada but that, despite being active for many years, still needs to be developed. Their functionality is linked to their touristic resources and tourists needs, which should be more efficiently promoted.

Despite all, Mamoiada case shows a powerful cultural, gastronomic and wine tourism offer, however, based on the strengths of the territory. The importance of wine, in its complete economic chain, reinforces the strong bond between the community and its territory. This has led to the creation of new jobs, and the wine thus becoming an extraordinary tool for territorialisation and for mitigating depopulation. At the same time, environmental, historicalarchaeological and traditional values of great cultural landscapes are still undervalued and furthermore should be included in a functional network of integrated management of resources.

Moreover, Cannonau Wine Trail is still an inactive tool for tourism activity, which can be enabled, by increasing the network between the various municipalities and the various related activities.

This paper is proposed as a pilot case that could provide a useful tool to be used as a pattern for other local winegrowing, being perfectible at national and international level of integrated regional strategy due to mitigation initiatives of depopulation in mountain areas. At the same time, it could be an example for the promotion and enhancement of local resources.

An attempt has been made to demonstrate how the marginal areas, which characterize the inland and mountainous areas, are somehow less decisive for the territory of Mamoiada. In fact, in the recent years there has been a reverse trend, driven by an important cultural and economic dynamism, thanks, above all, to wine production and the presence of significant endogenous resources.

Thus, wine becomes a tool to improve local development, a mechanism which could be used to mitigate depopulation effects and, through the vineyard development, there has been a greater control of the environment and the territory planning. If land abandonment is reduced, the hydrogeological risk is reduced, the enhancement of the landscape and local identities is encouraged, and new jobs are created, leading to local development.

Acknowledgement: This research was supported by funding from the "Fondo Ateneo per la ricerca - University of Sassari 2020 - CARBONI". This study was presented at Promountain International Conference, Bucharest, 2021. The author contributions: Donatella Carboni: 
conceptualization, data curation, methodology, resources, supervision, writing - review \& editing. Giampietro Mazza: conceptualization, data curation, investigation, methodology, validation, writing - original draft, writing - review \& editing. Marius Andra: translate, reviewing. AndreeaAndra Topârceanu: conceptualization, data curation, formal analysis, methodology, validation, writing - review \& editing.

\section{References}

1. Bacchetta, G., Bagella, S., Biondi, E., Farris, E., Filigheddu, R., Mossa, L., 2009. Vegetazione forestale e serie di vegetazione della Sardegna (con rappresentazione cartografica alla scala 1:350.000), Fitosociologia, 46(1) suppl. 1, p. 3-82.

2. Bartoloni, P., 2012. Produzione e commercio del vino in Sardegna nell'VIII secolo a.C., in Cocco, M. B., Gavini, A., Ibba, A., (eds), L'Africa Romana, Trasformazione dei paesaggi del potere nell'Africa settentrionale fino alla fine del mondo antico, Vol. 2, Carocci ed., Roma, p. 1845-1866.

3. Bentivoglio, D., Savini, S., Finco, A., Bucci, G., Boselli, E., 2019. Quality and origin of mountain food products: the new European label as a strategy for sustainable development, Journal of Mountain Science, 16(2), p. 428-440. https://doi.org/10.1007/s11629-018- 4962-x.

4. Boi, M., Fercia, M.L., Lonis, R., Lai, A., Lavena, A., Melis, E.B., Muntoni, F., 2019. Cartografia geotematica Carta Litologica della Sardegna 1:25000, ARPAS (accessed 18 Nov., 2021)

5. Bošković, N., Vujičić, M., Ristić, L., 2020. Sustainable tourism development indicators for mountain destinations in the Republic of Serbia. Curr Issues Tour, 23(22), p.2766-2778.

6. Brandis, P., 1979. Considerazioni geografiche sull'applicazione del piano agricolo-alimentare in Sardegna, Università degli Studi di Sassari, Istituto di Scienze geografiche, tip. Grafopress, Ozieri.

7. Bratoveanu, D.B., Costea (Voinea), RB., Mansour, J., and Stanciu, S., 2021. Mountain Products. A Lot of Opportunities for Romanian Food Producers. In (eds) Pamfilie, R., Dinu, V., Tăchiciu, L., Pleșea, D., Vasiliu, C. 7th BASIQ International Conference on New Trends in Sustainable Business and Consumption. Foggia, Italy, 3-5 June 2021. Bucharest: ASE, p.921-929, DOI: 10.24818/BASIQ/2021/07/115.

8. Carbone, L., Ciaschi, A., 2014. Le aree interne: dalla resilienza alla rinascita, in (eds) Capineri, C., Celata, F., De Vincenzo, D., Dini, F., Randelli, F., Romei, P., Memorie geografiche. Oltre la Globalizzazione Resilienza /Resilience, Società di Studi Geografici, p. 267-270.

9. Carboni, D., Ginesu, S., 2007. La geografia e il paesaggio del vino in Sardegna, ESPACIO Y TIEMPO, Revista de Ciencias Humanas, 21, p. 41-64.

10. Casalis, G., 1856. Dizionario Geografico - Storico - Statistico - Commerciale degli Stati di S.M. il Redi Sardegna, Maspero, Torino.

11. Ciaschi, A., 2014, Le mie montagne. Metodi identificativi di esperienze montane, Bologna, Bononia University Press, p.1-124.

12. Climate-data https://en.climate-data.org/europe/ (accessed 28 Nov., 2021).

13. Consorte, A., Delogu, G., Peretto, R., Saiu, L., 2021. La filiera vitivinicola, Scenario nazionale, Rapporto di analisi 2021, Agenzia Laore Sardegna, https://www.lestradedelvino.com/wpcontent/uploads/2021/03/sardegna_filiera_vitivinicola_report_regionale_2020.pdf.

14. Corsale, A., Iorio, M., 2008. Musei di identità e processi di sviluppo del turismo culturale L'esperienza del Museo delle Maschere Mediterranee di Mamoiada, Sardegna, https://crenos.unica.it/crenos/sites/default/files/08-02.pdf (accessed on 3 Nov., 2021).

15. Corsale, A., 2013. Esperienze di partecipazione e sviluppo del turismo rurale tra Sardegna e Romania, Istituto di Storia dell'Europa Mediterranea Consiglio Nazionale delle Ricerche, p.155-181.

16. Cunha, L., 2003. A montanha do Centro Português: Espaço de refúgio, Território marginal e recursos para o desenvolvimento local, in Cateano, L., (eds), Território ambiente e trajetórias de desenvolvimento, CEG, FLUC, Coimbra, p.175-191.

17. Deleuze, G., Guattari, F., 1975. L'anti-Edipo. Capitalismo e schizofrenia, Einaudi, Torino.

18. Dematteis, G., 2013.Montagna e aree interne nelle politiche di coesione territoriale italiane ed europee, Territorio, 66, p. 7-15, Franco Angeli, Milano.

19. Dematteis, G., Governa, F., 2005.Territorialità, sviluppo locale, sostenibilità: Il modello SLoT, Franco Angeli editore, Milano.

20. Euromontana, 2021. Mountain farming and rural areas in Europe, [online] Available at: https://www.euromontana.org (accessed on 27 Nov., 2021).

21. European Union, 2016. Dichiarazione di Cork 2.0, .1-12, DOI: 10.2762/011384.

22. Gentileschi, M.L., 1995. Sardegna emigrazione, Della Torre, Cagliari. 
23. Ginesu, S., 1999. Sardegna, aspetti del paesaggio fisico in un microcontinente, Università degli Studi di Sassari, Sassari.

24. Haesbaert, R., 2010. O mito da desterritorialização, Bertrand Brasil, Rio de Janeiro.

25. Haesbaert, R., 2013. Identidades territoriais, (eds) Rosendahl, Z., Lobato Corrêa, R., Geografia Cultural Vol II, Ed UERJ, Rio de Janeiro.

26. Italian National Institute of Statistic (ISTAT), 2021. A-Z STATISTICS (accessed on 9 Nov., 2021).

27. Jess, P., and Massey, D., 2001. Luoghi contestati, in Massey D. e Jess P. (eds), Luoghi, culture e globalizzazione, Utet, Torino, p.97-143.

28. Khartishvili, L., Mitrofanenko, T., Muhar, A., Penker, M., 2020. Issues with Applying the Concept of Community-Based Tourism in the Caucasus, Mountain Research and Development, 40(1), p. R11R20. https://doi.org/10.1659/MRD-JOURNAL-D-19-00071.1.

29. Le Lannou, M., 1941. Pâtres et paysans de la Sardaigne, Arrault, Tours.

30. Manola, M., and Koltsikoglou, G., 2020. Cultural experimental wine routes in Italy - Tuscany, Journal Sustanable Development, Culture, Tradition,1c, Tribute to Italy, p. 30-35.

31. Mazza, G., Madau C., Masia, S., Murtinu, F., 2018. Lo spopolamento come causa della deterritorializzazione: il caso dell'Unione dei Comuni Barbagia, in Sechi Nuvole, M., (eds), Antropizzazione, turismo e innovazione tecnologica. Un approccio multiscalare per l'analisi dello sviluppo sostenibile e intelligente del territorio, Supplemento Geotema, 3, Patron ed., Bologna, p.23-35.

32. Milićević, S., Bošković, N., Lakićević, M., 2021. Sustainable tourism development in mountain areas in Šumadija and Western Serbia. J. Mt. Sci. 18, p. 735-748. https://doi.org/10.1007/s11629-020-6239-4

33. Minnei, A.M.I., Massa, M.C., Pitzalis, G., Ravenna, M., Tiddia, B., 2018. Sardegna in cifre 2018. Il nuovo assetto territoriale, Regione autonoma della Sardegna.

34. Mori, A., 1975. Sardegna, Tipografia sociale torinese, Torino.

35. Price, M. F., Arnesen, T., Gløersen, E., Marc, J., Metzger, M. J., 2019. Mapping mountain areas: learning from Global, European and Norwegian perspectives, Journal of Mountain Science 16(1), p. 1-15.

36. Sotte, F., 2010. La politica di sviluppo rurale dell'EU. Riflessioni a margine del dibattito italiano, Q.A, Rivista dell'Associazione Rossi-Doria, p.125-135, DOI: 10.3280/QU2010-001007.

37. Št’astná, M., Vaishar, A., Ryglová, K., Rašovská, I., Zámečník, S., 2020. Cultural Tourism as a possible driver of rural development in Czechia. Wine tourism in Moravia as a case study, Europ. Countrys., 12(3), p. 292-311. DOI: 10.2478/euco-2020-0017.

38. Strade del vino - Legge 27 luglio 1999, n. 268' Disciplina delle "strade del vino" 'pubblicata nella Gazzetta Ufficiale n. 185 del 9 agosto 1999.

39. Zucca, R., 2009. Il vino in Sardegna nell'antichità, in La Vernaccia di Oristano, Atti del Seminario, Oristano, 15 maggio 2009, p. 45-50.

40. Wheater Atlas https://www.weather-atlas.com/en/italy/mamoiada-climate (accessed 28 Nov., 2021 ).

(C) 2021 by the authors. Submitted for possible open access publication under the terms and conditions of the Creative Commons AttributionNonCommercial-No Derivatives (CC BY NC ND) 4.0 International License. (https://creativecommons.org/licenses/by-nc-nd/4.0/). 